\title{
ПРОЕКТИРОВАНИЕ РАСПОЛОЖЕНИЯ ПЛОЩАДОК НАКОПЛЕНИЯ ТВЕРДЫХ КОММУНАЛЬНЫХ ОТХОДОВ НА ТЕРРИТОРИИ ЧАСТНОГО СЕКТОРА ГОРОДА НОВОСИБИРСКА
}

\author{
Мария Юрьевна Сидорова \\ Мэрия города Новосибирска, 630099, Россия, г. Новосибирск, ул. Трудовая, 1, кандидат техни- \\ ческих наук, начальник отдела охраны окружающей среды департамента энергетики, жилищ- \\ ного и коммунального хозяйства города, тел. (383)228-89-88, e-mail: Msidorova@admnsk.ru
}

\section{Андрей Геннадиевич Шарикалов}

Мэрия города Новосибирска, 630099, Россия, г. Новосибирск, ул. Трудовая, 1, заместитель начальника отдела охраны окружающей среды департамента энергетики, жилищного и коммунального хозяйства города, тел. (383)228-88-17, e-mail: asharikalov@admnsk.ru

\section{Алексей Викторович Дубровский}

Сибирский государственный университет геосистем и технологий, 630108, Россия, г. Новосибирск, ул. Плахотного, 10, кандидат технических наук, зав. кафедрой кадастра и территориального планирования, тел. (383)361-01-09, e-mail: avd5@ssga.ru

\section{Анатолий Викторович Ершов}

Сибирский государственный университет геосистем и технологий, 630108, Россия, г. Новосибирск, ул. Плахотного, 10, кандидат технических наук, старший преподаватель кафедры кадастра и территориального планирования, тел. (383)361-01-09, e-mail: er-tos@inbox.ru

В статье дано описание результатов выполненной работы по гранту Правительства города Новосибирск «Геоинформационный анализ определения земельных участков для размещения стационарных площадок накопления твердых коммунальных отходов на территории частного сектора города Новосибирска». Грант выполнялся сотрудниками кафедры кадастра и территориального планирования СГУГиТ. В ходе выполнения работ было запроектировано положение 2300 площадок накопления твердых коммунальных отходов. При определении оптимального места размещения площадки учитывались как общие требования санитарных правил и норм действующего законодательства, так и специфические особенности территории: расположение остановок общественного транспорта, маршруты передвижения населения, а также размещение объектов социально-бытового значения.

Ключевые слова: геоинформационная база данных, площадки накопления твердых коммунальных отходов, территория частного сектора, земельные участки, кадастровый план территории, геоинформационный анализ, топографический план

\section{DEVELOPMENT OF A GEO-INFORMATION DATABASE ON SOLID MUNICIPAL WASTE STORAGE SITES IN THE CITY OF NOVOSIBIRSK}

\section{Mariya Y. Sidorova}

Novosibirsk City Hall, 1, Trudovaya St., Novosibirsk, 630099, Russia, Ph. D., Head of the Environmental Protection Department, Department of Energy, Housing and Communal Services of the City, phone: (383)228-89-88, e-mail: Msidorova@admnsk.ru 


\section{Andrey G. Charikalov}

Novosibirsk City Hall, 1, Trudovaya St., Novosibirsk, 630099, Russia, Deputy Head of the Environmental Protection Department, Department of Energy, Housing and Communal Services of the City, phone: (383)228-88-17, e-mail: asharikalov@admnsk.ru

\section{Alexey V. Dubrovsky}

Siberian State University of Geosystems and Technologies, 10, Plakhotnogo St., Novosibirsk, 630108, Russia, Ph. D., Head of the Department of Cadastre and Territorial Planning, phone: (383)361-01-09, e-mail: avd5@ssga.ru

\section{Anatoly V. Ershov}

Siberian State University of Geosystems and Technologies, 10, Plakhotnogo St., Novosibirsk, 630108, Russia, Ph. D., Associate Professor, Department of Cadastre and Territorial Planning, phone: (383) 361-01-09, e-mail: er-tos@inbox.ru

The article presents the results of the work on the grant of the Government of the city of Novosibirsk "Geoinformation analysis of the definition of land plots for the placement of stationary sites for the accumulation of solid municipal waste on the territory of the private sector of the city of Novosibirsk". The study was carried out by the staff of the Department of Cadastre and Territorial Planning of SSUGT. Diagrams of the location of 2300 sites for the accumulation of solid municipal waste were drawn up. When determining the optimal location of the solid municipal waste storage site, the requirements of sanitary rules and current legislation were taken into account. The specific features of the territory like public transport stops, routes of movement of the population, social and household objects were taken into account.

Keywords: geoinformation database, solid municipal waste storage sites, private sector territory, land plots, cadastral plan of the territory, geoinformation analysis, topographic plan

Для территории города Новосибирск в 2019 году была разработана геоинформационная база данных площадок накопления ТКО для сбора и вывоза мусора из многоквартирных жилых домов [1]. Данные работы не были выполнены для территорий частного сектора города Новосибирска. В настоящее время, вывоз мусора с территорий частного сектора города Новосибирск осуществляется специализированной организацией ООО «Экология-Новосибирск». В соответствии с Постановлением Правительства Российской Федерации от 12.11.2016 г. № 1156 и Постановлением Правительства Новосибирской области от 11.05 .2017 г. № 176-п на сегодняшний день заключено 306,5 тыс. договоров на вывоз ТКО с собственниками индивидуальных жилых строений [2]. Вывоз осуществляется от каждого домовладения. При этом на территории частного сектора появляются новые и увеличиваются существующие несанкционированные свалки ТКО. Отсутствие стационарных площадок накопления ТКО влияет на общее экологическое состояние территории и ведет к его ухудшению в результате появления новых стихийных свалок ТКО.

Для разработки проектной документации по выбору мест строительства стационарных площадок накопления ТКО на территории частного сектора города Новосибирск проведен комплекс проектных и исследовательских работ, с применением методов геоинформационного анализа. 
Планирование расположение участков для строительства площадок накопления ТКО на территории частного сектора выполнялось с соблюдением требований СанПиН 2.1.7.3550-19 [3]. Все требования систематизированы для определения оптимального положения площадок накопления ТКО на территории населенных пунктов с минимизацией экологического вреда окружающей природной среде, а также минимизации затрат на вывоз ТКО [4-7].

- расположение площадки на участках муниципальной собственности;

- площадка для сбора ТКО должна располагаться не ближе чем за 20 метров от жилых домов и не дальше чем 100 метров;

- до площадки должен быть возможен подъезд специализированного транспорта;

- площадки должны располагаться на путях дневной миграции населения;

- участок, выбранный под площадку ТКО не должен располагаться в зонах с особыми условиями использования, установленными для инженерных коммуникаций.

При выборе места размещения площадки накопления ТКО учитывается количество жителей, их плотность, маршруты дневной миграции населения, климатические и погодные условия территории, рельеф местности, принадлежность земельных участков, расположение объектов недвижимости и элементов инженерной, транспортной, социально-бытовой инфраструктуры, существующие стихийно образованные несанкционированные свалки мусора, рис. 1.
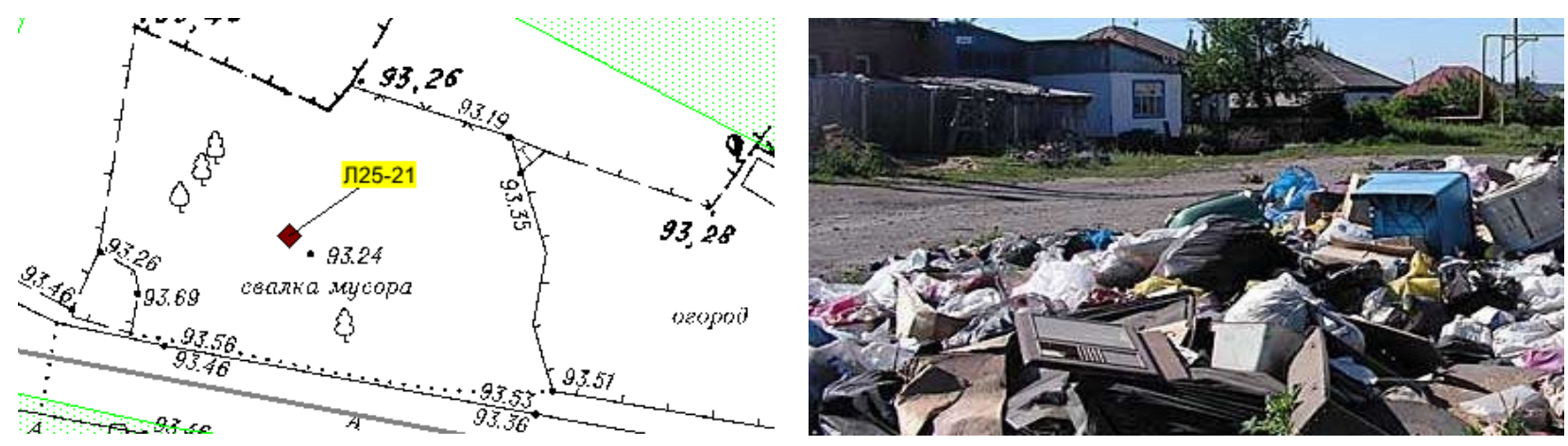

Рис. 1. Примеры несанкционированных стихийных мусорных свалок на территории частного сектора

Как правило, стихийные мусорные свалки возникают на участках, которые являются муниципальной собственностью, т.е. земельные участки у которых нет собственника в виде физического или юридического лица не огорожены и на них образуются несанкционированное складирование мусора. Подобные свалки несут в себе угрозу, как со стороны загрязнения земель и попадания опасных веществ в грунтовые воды, а далее в источники водоснабжения, например, в скважины, колодцы. Выявление подобных участков возможно как по результатам анализа картографического материала, так и на основании полевых 
обследований, в том числе и с применением технологий беспилотных авиасистем и данных дистанционного зондирования Земли

На основании созданного адресного плана на территорию частного сектора и выполненных дополнительных графических построений в виде буферных зон 20 метрового отступа от жилых домов и радиусов обслуживания в 100 метров относительно площадки накопления ТКО на землях муниципальной собственности было запроектировано местоположение 2303 центров земельных участков под площадки накопления ТКО. Всего требуется около 2634 площадки накопления ТКО в более чем 300 случаев установить площадку для обслуживания близлежащих жилых домов невозможно, так как не выполняются требования СанПиН 2.1.7.3550-19 [3].

При невозможности запроектировать центр земельного участка для строительства площадки накопления ТКО согласно решению по результатам Технического совещания со специалистами отдела охраны окружающей среды департамента энергетики, жилищного и коммунального хозяйства города Новосибирска, были запроектированы только радиусы возможного обслуживания жилых домов площадками накопления ТКО. Это необходимо для выявления общей потребности в площадках накопления ТКО на территории частного сектора.

Большинство случаев невозможности запроектировать площадку ТКО связаны с тем, что жилые дома находятся близко друг к другу и не соблюдается требование минимального расположения площадок ТКО. Второй наиболее распространенной причиной является отсутствие проекта для специализированной техники на земельный участок, удовлетворяющий необходимым требованиям в расстоянии от жилых домов. Местоположение всех запроектированных площадок накопления ТКО были уточнены по топографическим планам масштаба 1 : 500.

По результатам проведенных работ составлен каталог координат запроектированных центров площадок накопления ТКО. Также был выполнен анализ маршрутов передвижения населения до остановок общественного транспорта. В местах, где это возможно и не противоречит всем условиям расположения площадки накопления ТКО максимально близко на пути перемещения населения были запроектированы площадки. Также для определения наиболее перспективных с позиции использования площадок накопления ТКО и рекомендации их оборудования большим количеством контейнеров построена 250 метровая буферная зона относительно остановок общественного транспорта. Предполагаемая дневная миграция населения по маршрутам к остановкам общественного транспорта в среднем в 5 раз превышает число перемещений населения по другим маршрутам следования.

Пример оформления схемы проектируемого положения площадок накопления ТКО показан на рис. 2 . 

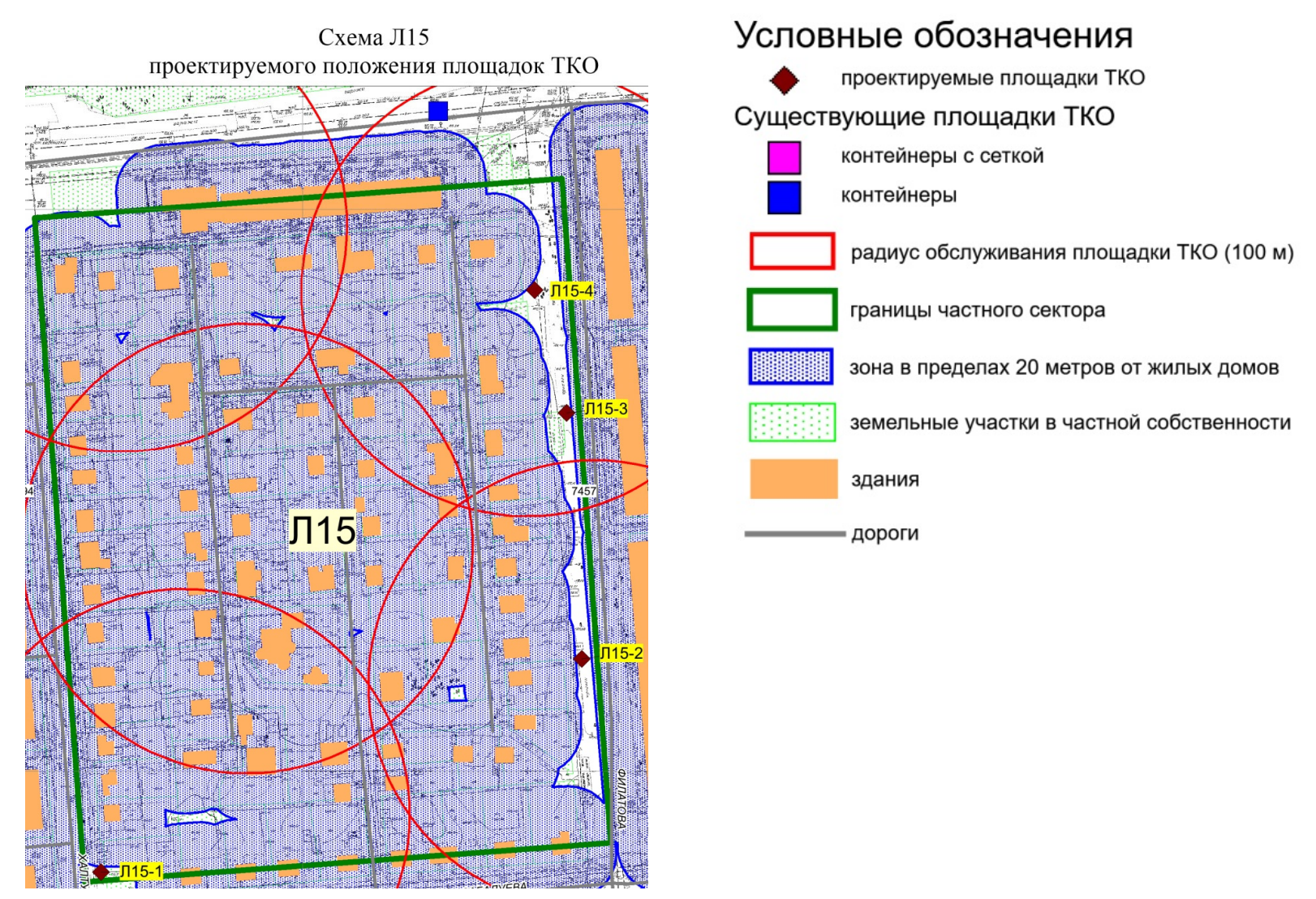

Рис. 2. Схема проектируемого положения площадок накопления ТКО

Экономическая эффективность внедрения в процесс территориального управления геоинформационной базы данных по площадкам накопления твердых коммунальных отходов на территории частного сектора города Новосибирска выражается в определении оптимального места размещения площадки, экономии временных и финансовых ресурсов при вывозе ТКО, а также увеличения количества собираемых ТКО. Социальная эффективность проекта выражается в возможности предоставления информации, широкому кругу пользователей, включая население города. Благодаря размещению геоинформационной базы данных по сведениям о площадках накопления твердых коммунальных отходов на территории города Новосибирска в сети интернет в виде общедоступного информационного ресурса возможно создание нового оригинального подхода к организации экологического воспитания и формирования экологической культуры в области обращения с твердыми коммунальными отходами у населения.

\section{БИБЛИОГРАФИЧЕСКИЙ СПИСОК}

1. Сидорова М. Ю., Шарикалов А. Г., Дубровский А. В., Ершов А. В., Ильиных А. Л. Разработка геоинформационной базы данных о площадках накопления твердых коммунальных отходов на территории города Новосибирска.- Регулирование земельно-имущественных отношений в России: правовое и геопространственное обеспечение, оценка недвижимости, экология, технологические решения : сб. материалов третьей национальной научно-практической конференции, 27-29 ноября 2019 г., Новосибирск. - Новосибирск : СГУГиТ, 2020, -С. 165 - 172, DOI 10.33764/2687-041X-2020-1-165-172. 
2. Об обращении с твердыми коммунальными отходами и внесении изменения в постановление Правительства Российской Федерации от 25 августа 2008 г. № 641 Постановление Правительства РФ от 12 ноября 2016 г. № 1156 [Электронный ресурс] - Режим доступа: https://www.garant.ru/products/ipo/prime/doc/71440160/.- Загл. с экрана.

3. Об утверждении санитарно-эпидемиологических правил и норм СанПин 2.1.7.3550-19 «Санитарно-эпидемиологические требования к содержанию территорий муниципальных образований». Главный государственный санитарный врач Российской Федерации Постановление от 5 декабря 2019 года № 20 [Электронный ресурс] - Режим доступа : http://docs.cntd.ru/document/564067935. - Загл. с экрана.

4. Об утверждении порядка накопления твердых коммунальных отходов (в том числе их раздельного накопления) на территории Новосибирской области (с изменениями на 21 сентября 2020 года). Постановление Правительства Новосибирской области от 11 мая 2017 года № 176-п [Электронный ресурс] - Режим доступа: http://docs.cntd.ru/document/465716954. Загл. с экрана.

5. Уставич Г.А., Дубровский А.В., Пошивайло Я.Г., Грекова А.О., Малыгина О.И. Элементы методики рационального землепользования территории полигонов твердых бытовых отходов. - Вестник СГУГиТ. - Том 24, № 3, 2019.- С. 203 - 221.

6. Сизов А. П. Мониторинг городских земель с элементами их охраны: учеб. пособие для студентов вузов по спец.: «Исслед. природ. ресурсов аэрокосм. средствами», «Приклад. геодезия». - М. 2000. - 157 с.

7. Управление отходами. Сточные воды и биогаз полигонов захоронения твердых бытовых отходов / под ред. Я. И. Вайсмана. - Пермь: Пермский нац. исслед. политехнический унт, 2012. $-258 \mathrm{c}$.

(C) М. Ю. Сидорова, А. Г. Шарикалов, А. В. Дубровский, А. В. Ершов, 2021 